\title{
Sources of pore water in a Tanegashima mud volcano inferred from chemical and stable isotopic studies
}

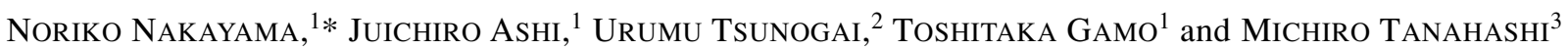 \\ ${ }^{1}$ Atmosphere and Ocean Research Institute, The University of Tokyo, 5-1-5 Kashiwanoha, Kashiwa, Chiba 277-8564, Japan \\ ${ }^{2}$ Earth and Planetary Sciences, Graduate School of Science, Hokkaido University, N10 W8, Kita-ku, Sapporo 060-0810, Japan \\ ${ }^{3}$ Japan Oil, Gas and Metals National Corporation, 1310, Omiya-cho, Saiwai-ku, Kawasaki, Kanagawa 212-8554, Japan
}

(Received June 17, 2009; Accepted July 10, 2010)

\begin{abstract}
Pore waters at the depths of 0-590 cm below seafloor (bsf) were collected from four core samples at four different sites in a mud volcano off Tanegashima Island between Ryukyu trench and Ryukyu arc of Japan. Concentrations of $\mathrm{Cl}^{-}$, $\mathrm{SO}_{4}{ }^{2-}, \mathrm{CH}_{4}, \mathrm{C}_{2} \mathrm{H}_{6}$ and stable isotopic composition of $\delta^{13} \mathrm{C}_{\mathrm{CH} 4}, \delta^{18} \mathrm{O}_{\mathrm{H} 2 \mathrm{O}}, \delta \mathrm{D}_{\mathrm{H} 2 \mathrm{O}}$ in the pore waters vary as a function of distance from seafloor. This paper reports and discusses the pore waters collected at the summit (CV) site. The concentrations of $\mathrm{Cl}^{-}$decrease from 540 at the seafloor to $375 \mathrm{mmol} / \mathrm{kg}$ at a depth of $\sim 200 \mathrm{~cm}$ and remain constant at around 350 $\mathrm{mmol} / \mathrm{kg}$ (64\% of the concentration of seawater) below the depth. The concentrations of $\mathrm{CH}_{4}$ are two to three orders of magnitude higher than those at other sites and have a maximum value of $715 \mu \mathrm{mol} / \mathrm{kg}$ at around $120-140 \mathrm{~cm}$ bsf. Core samples collected at depths deeper than $180 \mathrm{~cm}$ bsf show collapsing gas bubbles and empty voids when they were split open. It was also observed that liquid seeped out from the surface of the split core. Considering the physical condition is favorable for the formation of methane hydrate, the observations suggest the existence of methane hydrates. High concentration of $\mathrm{C}_{2} \mathrm{H}_{6}$, which had similar depth profile to that of $\mathrm{CH}_{4}$, was also observed. $\mathrm{C}_{2} \mathrm{H}_{6} / \mathrm{CH}_{4}$ ratio remained larger than $10^{-3}$ and $\delta^{13} \mathrm{C}_{\mathrm{CH} 4}$ also remained around $-45 \%$ oblow $180 \mathrm{~cm}$ bsf. The data suggest presence of thermogenic methane in the $\mathrm{CV}$ site. $\delta^{18} \mathrm{O}_{\mathrm{H} 2 \mathrm{O}}$ and $\delta \mathrm{D}_{\mathrm{H} 2 \mathrm{O}}$ profiles exhibited an opposite depth dependence, and only $\delta \mathrm{D}_{\mathrm{H} 2 \mathrm{O}}$ showed a decreasing depth profile similar to the concentration profile of $\mathrm{Cl}^{-}$. They were inversely correlated with the concentration of $\mathrm{Cl}^{-}$. The data of these two isotope compositions suggest a dilute fluid originates mainly from clay mineral dehydration but meteoric water. A simple mixing model of fluids from three sources (ambient seawater, water dissociated from methane hydrates, and diagenetic water ascending from deeper depth) with isotopic fraction during methane hydrate dissociation was applied for the observation result below $280 \mathrm{~cm}$ bsf to constrain ranges of $\delta^{18} \mathrm{O}_{\mathrm{H} 2 \mathrm{O}}$ and $\delta \mathrm{D}_{\mathrm{H} 2 \mathrm{O}}$ of diagenetic water. Using the observed depth profile of $\mathrm{Cl}^{-}$as a conservative component of ambient seawater, contribution of ambient seawater is estimated to be $64 \%$ whereas $36 \%$ from other two sources. Considering an isotopic fractionation during methane hydrate dissociation and using the estimated source fractions and observed isotopic composition of pore water, $\delta^{18} \mathrm{O}_{\mathrm{H} 2 \mathrm{O}}$ and $\delta \mathrm{D}_{\mathrm{H} 2 \mathrm{O}}$ of the diagenetic water were estimated to range from +15 to $+22 \%$ and from -103 to $-43 \%$, respectively, which are in good agreement with isotopic compositions of water formed from clay minerals during their dehydration but quite different from those of meteoric water, supporting negligible contribution of meteoric water in the Tanegashima mud volcano fluid.
\end{abstract}

Keywords: water chemistry, mud volcano, fluid migration, clay mineral dehydration, stable isotopic composition

\section{INTRODUCTION}

Submarine mud volcanoes have been found worldwide on continental shelves and slopes of accretionary wedges under compressional tectonic regime (Henry et al., 1990; Martin et al., 1996; Milkov, 2000; Dahlmann and de Lange, 2003). Mud volcanoes are considered to bring deep fluids together with mud to the surface and, provide useful information related to geochemical processes occur-

*Corresponding author (e-mail: noriko@aori.u-tokyo.ac.jp)

Copyright @ 2010 by The Geochemical Society of Japan. ring in deep accretionary sediments that are not readily available by other methods (Moore and Vrolijk, 1992; Henry et al., 1996; Hovland et al., 1998; Kopf et al., 2001). It has been also pointed out that gas hydrates commonly exist around mud volcanoes since they allows efficient migration of gases from deep to shallow depths in sedimentary rocks (Milkov, 2000; Waseda and Fujii, 2007).

Several mud volcanoes have been found on Tanegashima Island and more than 30 diapirs have been identified at the depth of 1200 to 3500 m below sea surface by acoustic sea floor survey along the Ryukyu Trench (Ujiié, 2000, references therein). The mud volcano in the 


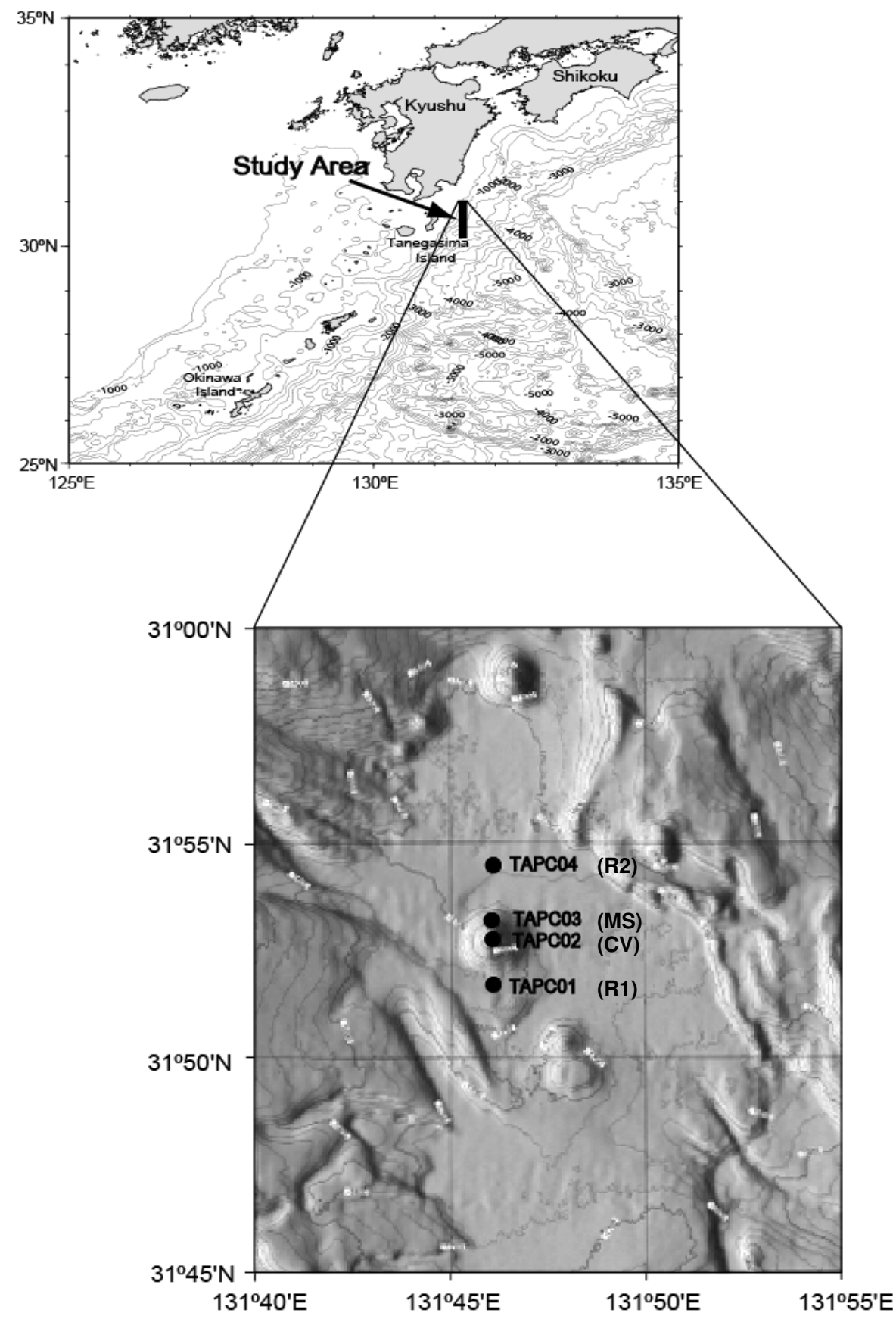

Fig. 1. Locations of four drill core sites in this study and seafloor topographic map. The bathymetric map was taken from Ujiié (2000). CV (TAPC02) and MS (TAPC03) refer the sites in the summit and the middle slope of the mud volcano, respectively. RI (TAPC01) and R2 (TAPC04) refer sites off the volcano regarded as a reference of ambient seafloor.

present study is among the ones which were previously identified (Ujiié, 2000). Despite the discovery of increasing number of mud volcanoes by geophysical survey in this area, no geochemical study has been carried out for mud volcanoes around Tanegashima Island. Geochemical information, such as chemical and their isotopic composition of pore water, is valuable in elucidating the origin of fluid below seafloor. This paper presents geochemical data of pore waters collected from four different sites in a Tanegashima mud volcano with special emphasis on a summit site, in which unusual depth profiles of chemical and isotopic compositions were observed. Using observed chemical and isotopic composition of the pore water, we will estimate relative contribution of different fluid 
Table 1. Concentrations of chemical components and composition of stable isotopes as a function of distance from seafloor in the pore waters collected for different sites in Tanegashima Mud volcano

\begin{tabular}{|c|c|c|c|c|c|c|c|c|c|}
\hline $\begin{array}{l}\text { Core No. } \\
\text { Location } \\
\text { Water depth }\end{array}$ & $\begin{array}{l}\text { Interval } \\
\text { (cmbsf) }\end{array}$ & $\begin{array}{c}\mathrm{Cl}^{-} \\
(\mathrm{mmol} / \mathrm{kg})\end{array}$ & $\begin{array}{c}\mathrm{SO}_{4}{ }^{2-} \\
(\mathrm{mmol} / \mathrm{kg})\end{array}$ & $\begin{array}{c}\delta^{18} \mathrm{O} \\
(\% \circ \mathrm{VSMOW})\end{array}$ & $\begin{array}{c}\delta \mathrm{D} \\
(\% \circ \mathrm{VSMOW})\end{array}$ & $\begin{array}{c}\mathrm{CH}_{4} \\
(\mu \mathrm{mol} / \mathrm{kg})\end{array}$ & $\begin{array}{l}\delta^{13} \mathrm{C}-\mathrm{CH}_{4} \\
(\% \circ \mathrm{VPDB})\end{array}$ & $\begin{array}{c}\mathrm{C}_{2} \mathrm{H}_{6} \\
(\mu \mathrm{mol} / \mathrm{kg})\end{array}$ & $\mathrm{C} 2 / \mathrm{C} 1$ \\
\hline R1 (TAPC01) & $0-5$ & 541 & 27.5 & -0.2 & -1.0 & 0.06 & -51.4 & - & - \\
\hline $30^{\circ} 51.70^{\prime} \mathrm{N}$ & $10-15$ & 546 & 27.5 & +0.2 & -1.3 & 0.06 & -51.4 & - & - \\
\hline $131^{\circ} 46.02^{\prime} \mathrm{E}$ & $70-90$ & 548 & 27.5 & -0.2 & -1.5 & 0.04 & -49.9 & - & - \\
\hline \multirow[t]{11}{*}{$1697 \mathrm{~m}$} & $100-110$ & 542 & 28.0 & +0.1 & -1.7 & 0.26 & -50.4 & - & - \\
\hline & $115-130$ & 554 & 28.0 & -0.0 & -1.2 & 0.11 & -57.0 & - & - \\
\hline & $130-145$ & 547 & 27.5 & +0.3 & -1.8 & 0.21 & -52.0 & - & - \\
\hline & $150-170$ & 551 & 28.0 & +0.3 & -0.6 & 0.18 & -58.9 & - & - \\
\hline & $230-250$ & 543 & 28.1 & +0.1 & -1.1 & 0.10 & -53.1 & - & - \\
\hline & $275-290$ & 546 & 27.1 & +0.3 & -1.2 & 0.48 & -42.8 & - & - \\
\hline & $355-375$ & 543 & 26.0 & +0.2 & -1.2 & 0.36 & -45.0 & - & - \\
\hline & $400-420$ & 541 & 26.0 & +0.3 & -1.2 & 0.25 & -45.1 & - & - \\
\hline & $460-480$ & 546 & 25.9 & +0.4 & -1.0 & 0.23 & -47.7 & - & - \\
\hline & $520-540$ & 546 & 26.1 & +0.5 & -1.2 & 0.10 & -47.6 & - & - \\
\hline & $570-590$ & 546 & 26.1 & +0.5 & -1.2 & 0.09 & -47.4 & - & - \\
\hline CV (TAPC02) & $0-5$ & 548 & 27.5 & +0.1 & +0.2 & 5.02 & -49.3 & 1.7 & 0.338 \\
\hline $30^{\circ} 52.74^{\prime} \mathrm{N}$ & $10-15$ & 555 & 27.3 & +0.2 & +0.5 & 3.04 & -51.6 & 0.3 & 0.103 \\
\hline $131^{\circ} 46.04^{\prime} \mathrm{E}$ & $20-40$ & 554 & 26.3 & +0.2 & +0.1 & 1.39 & -46.6 & 0.8 & 0.577 \\
\hline \multirow[t]{8}{*}{$1442 \mathrm{~m}$} & $40-60$ & 545 & 23.9 & +0.5 & -1.1 & 15.23 & -39.7 & 3.2 & 0.210 \\
\hline & $60-80$ & 538 & 19.4 & +0.5 & -3.5 & 62.60 & -43.3 & 16.8 & 0.269 \\
\hline & $120-140$ & 486 & 5.5 & +1.1 & -3.9 & 714.54 & -42.6 & 264.6 & 0.370 \\
\hline & $180-210$ & 375 & 0.3 & +3.2 & -10.4 & 115.64 & -40.7 & 22.2 & 0.192 \\
\hline & $230-250$ & 354 & 0.5 & +4.1 & -13.0 & 165.32 & -39.2 & 17.8 & 0.107 \\
\hline & $280-300$ & 348 & 0.9 & +5.4 & -15.7 & 81.80 & -41.9 & 6.0 & 0.074 \\
\hline & $330-350$ & 347 & 0.3 & +5.3 & -15.6 & 45.02 & -39.0 & 3.5 & 0.078 \\
\hline & $380-410$ & 349 & 0.7 & +5.5 & -16.7 & 53.47 & -42.7 & 3.3 & 0.061 \\
\hline MS (TAPC03) & $0-10$ & 551 & 27.9 & +0.3 & +0.1 & 1.37 & -48.4 & - & - \\
\hline $30^{\circ} 53.01^{\prime} \mathrm{N}$ & $10-20$ & 552 & 28.0 & +0.2 & -1.1 & 0.28 & -48.0 & - & - \\
\hline $131^{\circ} 46.01^{\prime} \mathrm{E}$ & $20-40$ & 554 & 28.0 & +0.4 & +0.0 & 0.06 & -42.8 & - & - \\
\hline \multirow[t]{9}{*}{$1564 \mathrm{~m}$} & $40-50$ & 553 & 27.4 & +0.4 & -0.1 & 5.66 & -53.6 & 0.27 & 0.047 \\
\hline & $60-80$ & 562 & 28.0 & +0.3 & -1.0 & 1.80 & -51.4 & 0.19 & 0.105 \\
\hline & $80-100$ & 556 & 27.1 & +0.2 & -2.0 & 0.72 & -54.0 & 0.23 & 0.319 \\
\hline & $100-120$ & 559 & 27.1 & +0.4 & -1.2 & 0.67 & -46.6 & 0.30 & 0.449 \\
\hline & $150-170$ & 554 & 25.8 & +0.1 & -1.1 & 2.91 & -52.0 & 0.21 & 0.074 \\
\hline & $200-210$ & 556 & 25.1 & +0.2 & -1.0 & 0.73 & -49.0 & - & - \\
\hline & $210-220$ & 558 & 24.7 & +0.3 & -2.2 & 0.29 & -45.9 & - & - \\
\hline & $250-270$ & 553 & 24.0 & +0.1 & -1.2 & 3.12 & -54.3 & - & - \\
\hline & $300-310$ & 556 & 24.3 & +0.3 & -1.7 & 0.18 & -43.1 & - & - \\
\hline R2 (TAPC04) & $0-5$ & 548 & 27.0 & +0.2 & -0.1 & 0.25 & -42.5 & - & - \\
\hline $30^{\circ} 54.48^{\prime} \mathrm{N}$ & $10-15$ & 548 & 26.9 & +0.2 & -0.8 & 0.28 & -47.0 & - & - \\
\hline $131^{\circ} 46.06^{\prime} \mathrm{E}$ & $35-55$ & 550 & 27.1 & +0.1 & -1.6 & 0.20 & -45.2 & - & - \\
\hline \multirow[t]{8}{*}{$1730 \mathrm{~m}$} & $55-75$ & 556 & 27.1 & +0.2 & -2.1 & 0.11 & -47.2 & - & - \\
\hline & $85-100$ & 550 & 26.6 & +0.2 & -2.0 & 0.10 & -47.3 & - & - \\
\hline & $110-130$ & 559 & 26.4 & +0.0 & -1.9 & 0.10 & -47.9 & - & - \\
\hline & $130-135$ & 550 & 26.4 & +0.2 & -1.6 & - & - & - & - \\
\hline & $180-200$ & 559 & 26.4 & +0.2 & -1.9 & - & - & - & - \\
\hline & $260-280$ & 554 & 27.7 & -0.1 & -2.1 & 0.23 & -49.2 & - & - \\
\hline & $310-330$ & 555 & 26.5 & -0.0 & -2.2 & 0.28 & -47.7 & - & - \\
\hline & $370-390$ & 554 & 26.5 & +0.1 & -1.6 & 0.20 & -49.9 & - & - \\
\hline
\end{tabular}



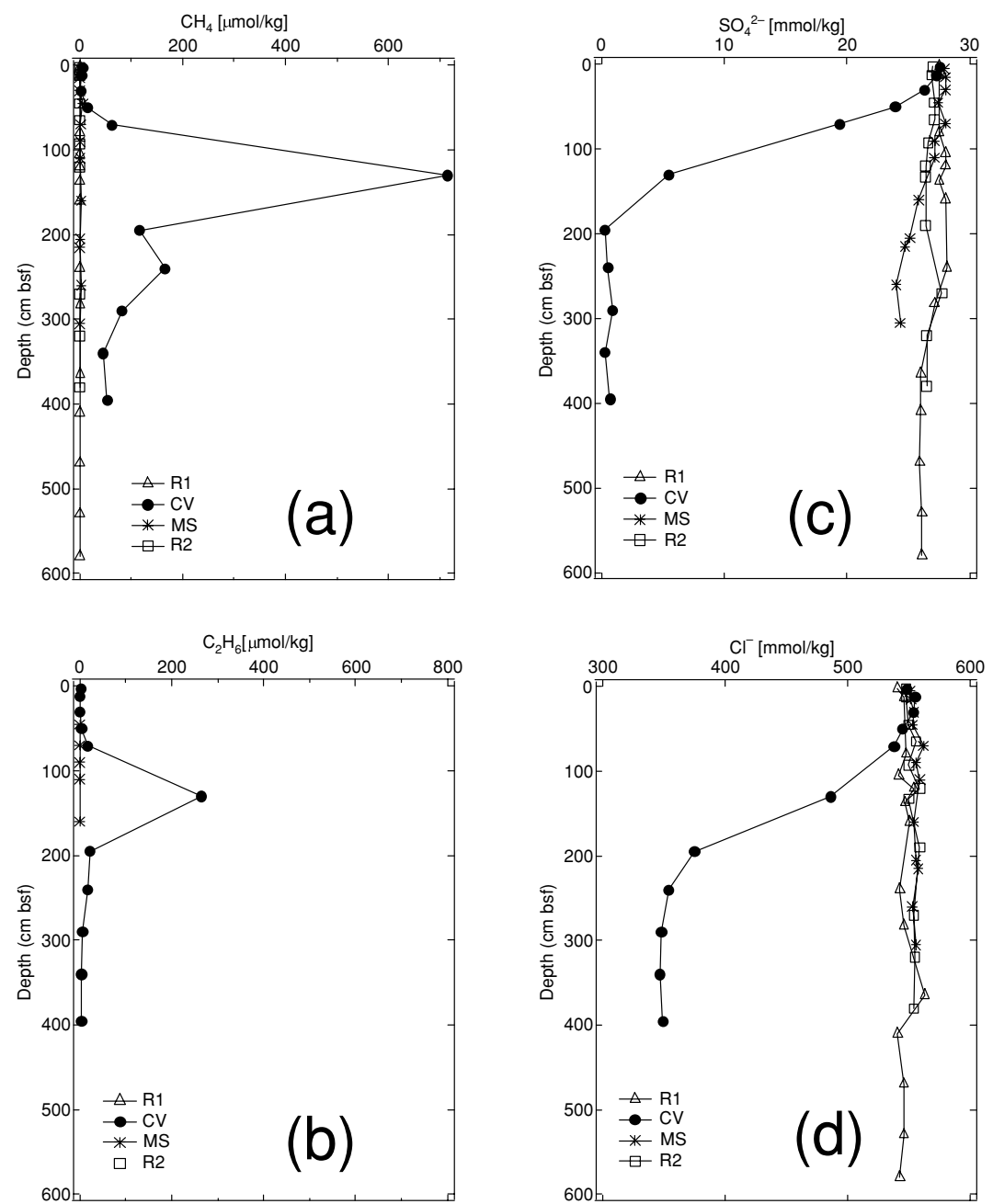

Fig. 2. Vertical profiles of concentrations of $\mathrm{CH}_{4}, \mathrm{C}_{2} \mathrm{H}_{6}, \mathrm{SO}_{4}{ }^{2-}$, and $\mathrm{Cl}^{-}$in the pore waters collected in the four different sites at a Tanegashima mud volcano. Solid circle, summit site (CV); star, middle of the volcano's slope (MS); open triangle and open square, off the volcano as a reference of ambient seafloor $(R 1, R 2)$.

sources to the pore water and show the importance of clay mineral dehydration in the fluid of the Tanegashima mud volcano.

\section{EXPERIMENTAL}

\section{Sampling and analytical methods}

Sediment sampling was conducted as a part of Metal Mining Agency of Japan (MMAJ) geochemical survey by R/V Hakurei-maru II in January 2002. Figure 1 shows locations of sediment core sampling. This mud volcano $\left(30^{\circ} 53^{\prime} \mathrm{N}, 131^{\circ} 46^{\prime} \mathrm{E}\right)$ was chosen for this extensive investigation based on the early survey in this area (Ujiié, 2000). Four piston core samples (TAPC01, TAPC02, TAPC03, and TAPC04) were collected from different sites of the mud volcano. The recovered sediment cores were $310-520 \mathrm{~cm}$ in length (Table 1). After recovering, the core samples were cut every $1 \mathrm{~m}$ interval. In the shipboard laboratory, pore waters were extracted from the sediment samples using a squeezer which was a modified version of one developed by Manheim (1966). After filtering the pore water through $0.45-\mu \mathrm{m}$ Millipore filter, the water samples were processed immediately in the shipboard laboratory before storing in a refrigerator. For the analyses of $\mathrm{CH}_{4}, \mathrm{C}_{2} \mathrm{H}_{6}$ and $\delta^{13} \mathrm{C}_{\mathrm{CH} 4}$, about $2 \mathrm{ml}$ of extracted pore water was immediately transferred to a $3 \mathrm{~cm}^{3}$ poisoned serum glass vial under oxygen-free $\mathrm{N}_{2}$ environment to prevent oxidation of methane. Then the glass vial was sealed with a butyl rubber septum with an aluminum caps and stored in a refrigerator. The remaining pore water was divided into two and put in a polypropylene bottle (for the analysis of $\mathrm{Cl}^{-}$and $\mathrm{SO}_{4}{ }^{2-}$ ) and a glass vial (for the analysis of $\delta^{18} \mathrm{O}_{\mathrm{H} 2 \mathrm{O}}$ and $\delta \mathrm{D}_{\mathrm{H} 2 \mathrm{O}}$ ) and stored in a refrigerator. All chemical analysis was carried out in the labora- 

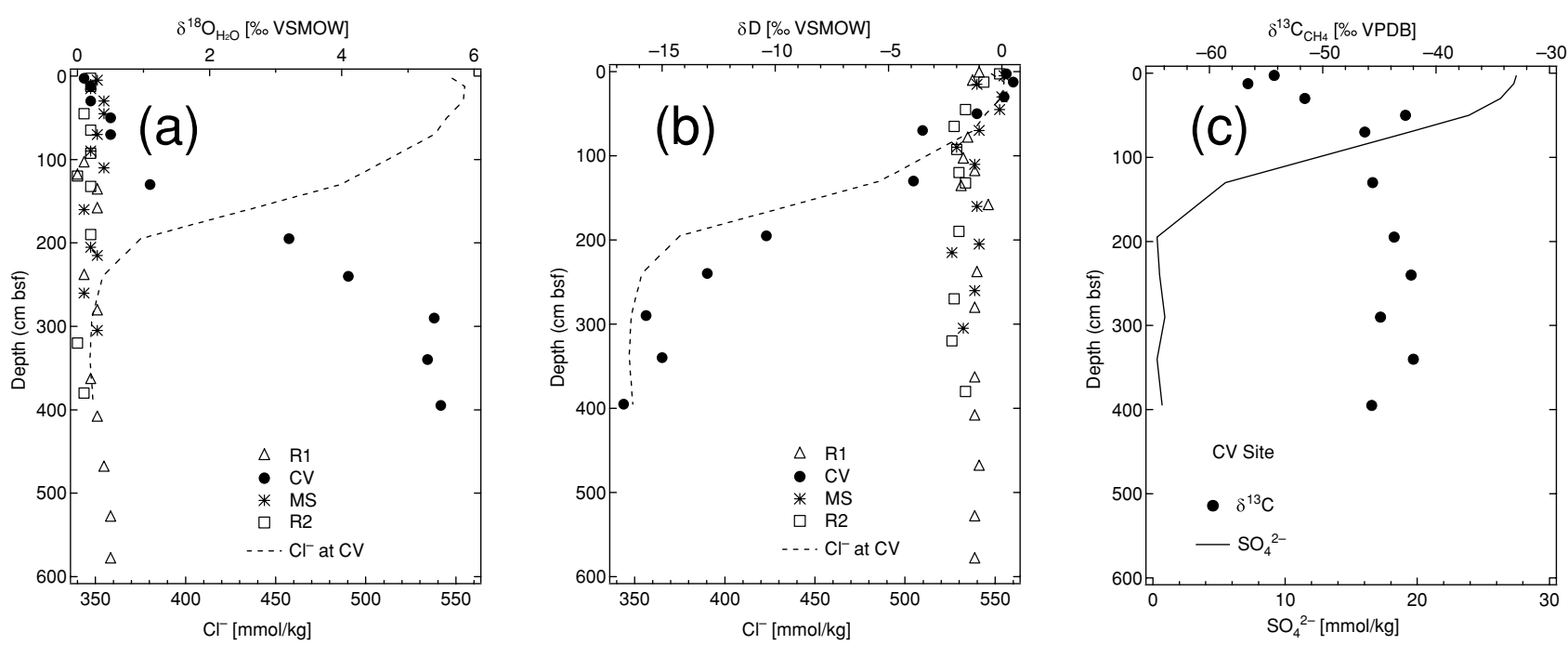

Fig. 3. Vertical profiles of (a) $\delta^{18} \mathrm{O}_{\mathrm{H} 2 \mathrm{O}}$ and $(b) \delta D_{\mathrm{H} 2 \mathrm{O}}$ of the pore waters collected at four different sites. The data from the $C V$ site

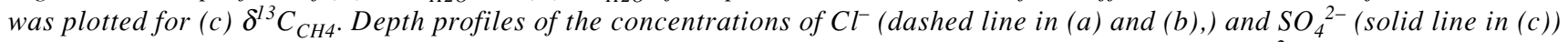
in the $\mathrm{CV}$ site were also plotted. The data are using the lower $\mathrm{X}$-axis for the concentrations of $\mathrm{Cl}^{-}$and $\mathrm{SO}_{4}{ }^{2-}$, and the upper $\mathrm{X}$-axis for isotopic compositions of (a) $\delta^{18} O_{H 2 O}$, (b) $\delta D_{H 2 O}$, and (c) $\delta^{13} C_{C H 4}$. Closed symbol, summit site (CV); cross symbol, middle of the volcano's slope $(M S)$; open triangle and open square, off the volcano as a reference of ambient seafloor $(R 1, R 2)$, respectively.

tory at Hokkaido University after the cruise. Totally, 48 samples of pore waters were obtained and analyzed in this study.

Concentrations and stable carbon isotope compositions of $\mathrm{CH}_{4}$ and $\mathrm{C}_{2} \mathrm{H}_{6}$ were simultaneously determined by an isotope ratio monitoring gas chromatography/mass spectrometry system which was specially designed for the isotope analysis of trace low-hydrocarbon species $\left(\mathrm{C}_{1}-\right.$ $\mathrm{C}_{3}$ ) (Tsunogai et al., 2002). Accuracy and precision for the isotope analysis was examined to be $\sim 0.3 \%$ o ( $1 \sigma$ for 10 measurements) using a 200 pmol of $\mathrm{CH}_{4}$ gas made from NIST RM8560 (IAEA NGS2). Precision of the $\mathrm{CH}_{4}$ measurement was $\sim 6.5 \%$ ( $1 \sigma$ for 10 measurements) at the concentration level of $2 \mathrm{nmol} / \mathrm{kg}$ of methane. The analytical blank for $\mathrm{CH}_{4}$ was negligibly small $(<1 \mathrm{pmol})$. A water- $\mathrm{CO}_{2}$ equilibration method (Epstein and Mayeda, 1953 ) was used for the determination of $\delta^{18} \mathrm{O}_{\mathrm{H} 2 \mathrm{O}}$. For the $\delta \mathrm{D}_{\mathrm{H} 2 \mathrm{O}}$ analysis, $2 \mu \mathrm{l}$ of water was reduced to $\mathrm{H}_{2}$ by reacting with $100 \mathrm{mg}$ of $\mathrm{Zn}$ in a Pyrex tube at $500^{\circ} \mathrm{C}$ (Coleman et al., 1982). Resultant $\mathrm{H}_{2}$ gas was analyzed using Finnigan Mat 252 mass spectrometer equipped with a dual inlet system. Precision of the $\delta \mathrm{D}_{\mathrm{H} 2 \mathrm{O}}$ analysis was $\sim 1 \%$. The concentrations of $\mathrm{Cl}^{-}$and $\mathrm{SO}_{4}{ }^{2-}$ were determined using an ion chromatograph with a precision of $\sim 3 \%$.

\section{RESULTS AND DISCUSSION}

Figure 3 shows depth profiles of the concentrations of $\mathrm{CH}_{4}, \mathrm{C}_{2} \mathrm{H}_{6}, \mathrm{SO}_{4}{ }^{2-}$ and $\mathrm{Cl}^{-}$in pore waters collected at the four sites. Only in the summit site (CV, TAPC02), unusual depth profiles were observed, while monotonous depth profiles with concentrations similar to those of ambient seawater were observed in other sites.

At the $\mathrm{CV}$ site, $\mathrm{CH}_{4}$ increased significantly from 5 to $715 \mu \mathrm{mol} / \mathrm{kg}$ in the segment from 0 to $140 \mathrm{~cm}$ bsf, and dropped to $50 \sim 80 \mu \mathrm{mol} / \mathrm{kg}$ at depths deeper than $140 \mathrm{~cm}$ bsf. In the other sites (R1, R2, and MS), $\mathrm{CH}_{4}$ concentration was quite low and showed a rather uniform depth profile $(0.1 \sim 0.5 \mu \mathrm{mol} / \mathrm{kg}$ for $\mathrm{R} 1$ and $\mathrm{R} 2,0.1 \sim 5 \mu \mathrm{mol} / \mathrm{kg}$ for MS, see Table 1). Collapsing gas bubbles and empty voids were observed in the core samples below $180 \mathrm{~cm}$ bsf at the CV site when the core was split open (National Oil Corporation, 2003). The evidence suggests gas escape from the core and the observed gas concentrations are much lower than the actual gas concentrations in the core. Therefore, reported gas concentrations represent minimum values. In spite of the escape of gasses, observed $\mathrm{CH}_{4}$ concentrations at the $\mathrm{CV}$ site were two to three orders of magnitude higher than those in other sites, and more than six orders of magnitude higher than that in ambient seawater. A high concentration of ethane, which had similar depth profile to that of methane, was also observed in the $\mathrm{CV}$ site samples. The concentration ratios of $\mathrm{C}_{2} \mathrm{H}_{6}$ to $\mathrm{CH}_{4}$ also remained above $10^{-3}$ at all depths. Since ethane is mainly produced through thermal decomposition of organic matter (Bernard et al., 1978; Whiticar, 1999), the observed relationship of methane and ethane is indicative for a primary contribution of thermogenic methane in the CV site. The proposed interpretation is also supported by similar $\delta^{13} \mathrm{C}_{\mathrm{CH} 4}$ values of $\sim 45 \%$ o below 

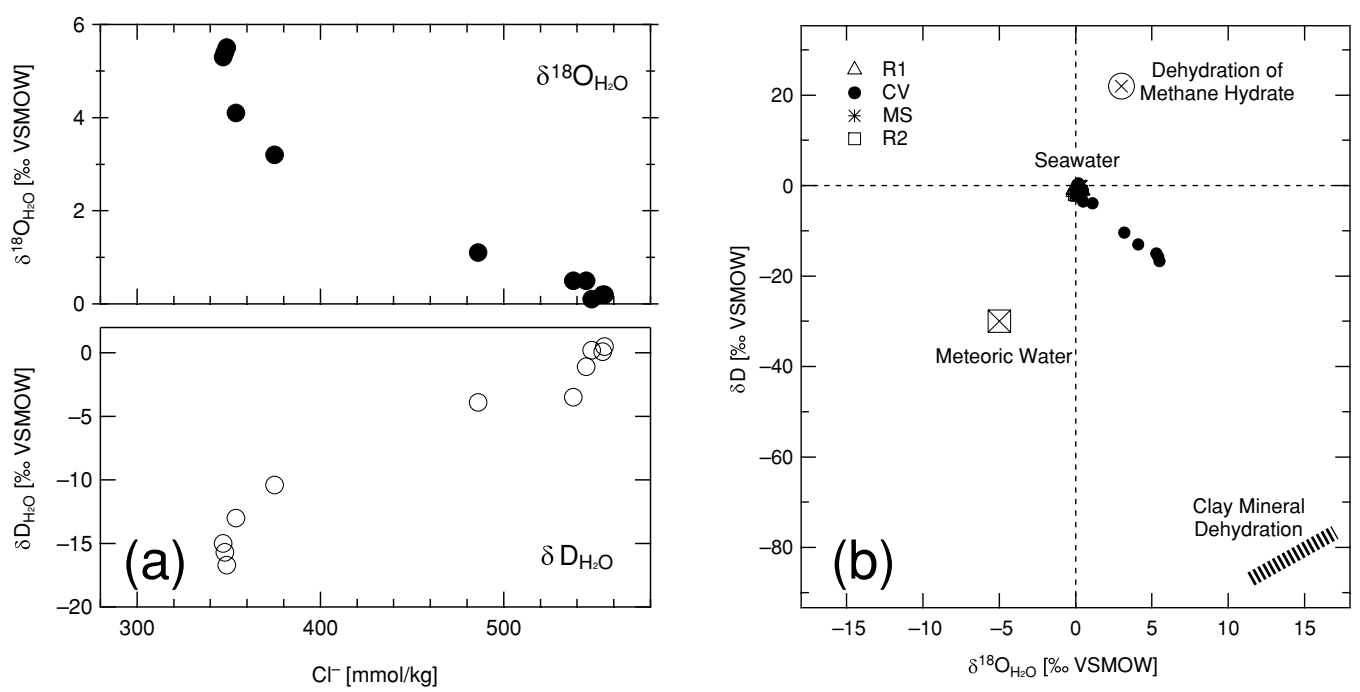

Fig. 4. (a) Correlation plot of isotopic compositions and $\mathrm{Cl}^{-}$concentrations in pore waters collected at the CV site (solid circle, $\delta^{I 8} \mathrm{O}_{\mathrm{H} 2 \mathrm{O}}$; open circle, $\delta D_{\mathrm{H} 2 \mathrm{O}}$ ). (b) $\delta^{18} \mathrm{O}_{\mathrm{H} 2 \mathrm{O}}$ and $\delta D_{\mathrm{H} 2 \mathrm{O}}$ of pore waters at four studied sites. Data from all depths at these sites were plotted on the figure. The data except for those from the $C V$ site are similar to seawater values and overlapped each other on the plot. As a reference, $\delta^{18} \mathrm{O}_{\mathrm{H} 2 \mathrm{O}}$ and $\delta D_{\mathrm{H} 2 \mathrm{O}}$ of the local meteoric water, waters formed during the dehydration of methane hydrate and clay minerals are also plotted. Solid circle, summit site $(C V)$; star, middle of the volcano's slope (MS); open triangle and square, off the volcano as a reference of ambient seafloor $(R 1, R 2)$.

$60 \mathrm{~cm}$ bsf (Fig. 3(c)). The thermogenic methane of $\delta^{13} \mathrm{C}_{\mathrm{CH} 4}$ ranges from roughly $-50 \%$ o to $-20 \%$, whereas that of the bacterial methane varying from $-110 \%$ to -50\%o (Bernard et al., 1978; Coleman and Risatti, 1981; Paull et al., 1994; Tilbrook and Karl, 1995; Whiticar, 1999).

On the other hand, unusually steep gradient of sulfate concentration decreased from 27 to $\sim 0 \mathrm{mmol} / \mathrm{kg}$ was also found in upper sediments at the $\mathrm{CV}$ site whereas the methane concentration increased by $\sim 0.7 \mathrm{mmol} / \mathrm{kg}$. It indicates the high rates of sulfate reduction compared to other sites (Fig. 2(c)). In methane-rich sediment, the concentration of $\mathrm{SO}_{4}{ }^{2-}$ is commonly depleted since sulfate-reducing bacteria consume $\mathrm{SO}_{4}{ }^{2-}$ during methane oxidation (Marty, 1993). In a closed system, the preferential removal of isotopically lighter methane during sulfate reduction results in a progressive shift in the $\mathrm{C}$ isotope compositions of residual methane towards ${ }^{13} \mathrm{C}$-enriched values. However, high concentration of methane at the study site results in a negligible contribution of the biological sulfate reduction to the isotopic composition of methane as observed in the CV site even when most of sulfate was reduced. Actually, much higher concentration of methane should have been existed in the porewater in the CV site samples, which is consistent with the escape of gases from the core, as described above.

An unusual depth profile of $\mathrm{Cl}^{-}$concentration was also observed at the CV site, whereas almost constant $\mathrm{Cl}^{-}$concentration was observed for all depths at other sites. At the seafloor $(0 \mathrm{~cm} \mathrm{bsf})$, the concentrations of $\mathrm{Cl}^{-}$were similar to that of seawater. At the CV site, the concentration of $\mathrm{Cl}^{-}$declined as increasing depth down to around $200 \mathrm{~cm}$ bsf and became constant below the depth. Since $\mathrm{Cl}$ ion is a conservative chemical component of ambient seawater, the $\mathrm{Cl}^{-}$concentration lower than the ambient seawater suggests a dilution of ambient seawater with fluids.

$\delta^{18} \mathrm{O}_{\mathrm{H} 2 \mathrm{O}}$ and $\delta \mathrm{D}_{\mathrm{H} 2 \mathrm{O}}$ exhibited clear depth-dependent variations at the $\mathrm{CV}$ site whereas no depth-dependent variation was observed in other sites (Figs. 3(a) and (b)). At the $\mathrm{CV}$ site, $\delta^{18} \mathrm{O}_{\mathrm{H} 2 \mathrm{O}}$ increased from 0 to $+5.4 \%$, while $\delta \mathrm{D}_{\mathrm{H} 2 \mathrm{O}}$ decreased from 0 to $-16 \%$ at depth from 0 to 280 $\mathrm{cm}$ bsf, showing that the two are inversely correlated. Below $280 \mathrm{~cm} \mathrm{bsf}, \delta^{18} \mathrm{O}_{\mathrm{H} 2 \mathrm{O}}$ and $\delta \mathrm{D}_{\mathrm{H} 2 \mathrm{O}}$ became constant $\left(+5 \%\right.$ and $-15 \%$, respectively). In the other sites, $\delta^{18} \mathrm{O}_{\mathrm{H} 2 \mathrm{O}}$ and $\delta \mathrm{D}_{\mathrm{H} 2 \mathrm{O}}$ stayed in the range from -0.2 to $+0.5 \%$ and -2.2 to $+0.1 \%$ in all depths, respectively. These values are similar to those of the seawater. It should be pointed out that $\delta^{18} \mathrm{O}_{\mathrm{H} 2 \mathrm{O}}$ and $\delta \mathrm{D}_{\mathrm{H} 2 \mathrm{O}}$ in the $\mathrm{CV}$ site samples show an inverse correlation when they were plotted against the concentration of $\mathrm{Cl}^{-}$(Fig. 4(a)). The data demonstrate the dilute water originates from clay minerals during their dehydration rather than from gas hydrate dissociation. It has been shown that mixing of meteoric water results in decreasing $\delta^{18} \mathrm{O}_{\mathrm{H} 2 \mathrm{O}}$ and $\delta \mathrm{D}_{\mathrm{H} 2 \mathrm{O}}$ for water (Dahlman and de Lange, 2003), while they changed to the opposite direction in the CV site as shown in Fig. 4(b). Similar isotopic comparison has been used to elucidate possible ori- 


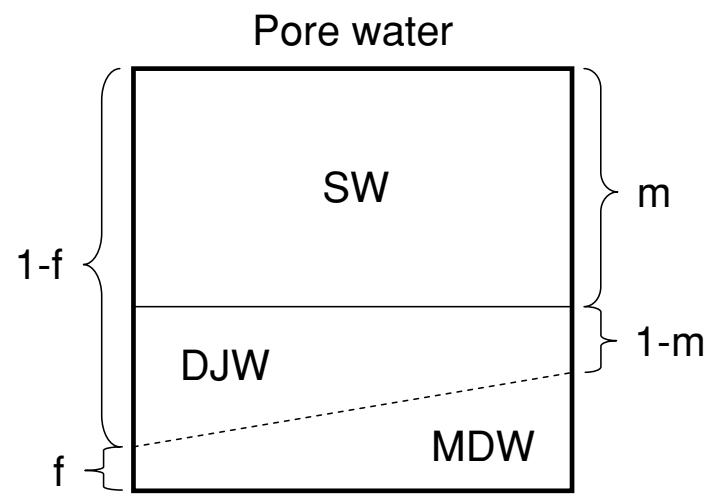

Fig. 5. Schematic diagram showing the simple mixing model of source waters used in this study. The model considers three sources: water generated by dehydration of methane hydrate $(M D W)$ and a diluted of ambient seawater with fluid (FLD). The FLD is composed of SW (ambient seawater) and DJW (diagenetic water). $f$ and $m$ stand for the relative contribution of waters and $S W$, respectively. All acronyms used in the figure are the same as those in the equations in the text.

gins of sediment pore waters at the high methane flux areas over the Japan Sea (Hiruta et al., 2009).

\section{Origin of diagenetic water in the $C V$ site}

Observed depth profiles suggest that fluid from deeper depth migrated through the sediment and mixed with ambient seawater in the shallow layers below seafloor, although $350 \mathrm{~mol} / \mathrm{kg}$ of $\mathrm{Cl}^{-}$below $200 \mathrm{~cm}$ bsf indicates that the fluid also contains significant amount of seawater. Only summit site (CV) exhibited the unusual depth profiles, which show that the mud volcano also has a "pathway for fluid migration" from deep sediments to seafloor in the vent area as reported in other mud volcanoes (e.g., Milkov, 2000) and the fluid may be brought from the deeper layer to the shallow sediment zone together with various chemical components. What is the origin of the fluid? As already mentioned, contribution of meteoric water can be excluded in the current study. Since high concentration of $\mathrm{CH}_{4}$ was observed and because the conditions in the site are in the stability field of methane hydrate, existence of methane hydrates should be also considered. Thus three possible sources of water are considered: (1) ambient seawater, (2) water dissociated from methane hydrates, and (3) water produced during the diagenesis of deep sediments.

A simple mixing model was applied to the observed results obtained below $280 \mathrm{~cm}$ bsf in the CV site to evaluate the sources of the water and estimate their relative contributions (Fig. 5). In our model, we assumed that methane hydrate below $200 \mathrm{~cm}$ bsf was formed by the interaction between methane and surrounding water (a mixture of ambient seawater and diagenetically produced water), which is represented as fluid in the following model equations.

The relationship between observed isotopic compositions of the pore water can be written as follows:

$$
\begin{aligned}
& \delta_{\mathrm{obs}}=f \cdot \delta_{\mathrm{mdw}}+(1-f) \cdot \delta_{\mathrm{fld}} \\
& \delta_{\mathrm{mdw}}=\delta_{\mathrm{fld}}+(\alpha-1) \cdot 10^{3} \\
& \delta_{\mathrm{fld}}=m \cdot(1-f) \cdot \delta_{\mathrm{sw}}+(1-m)(1-f) \cdot \delta_{\mathrm{djw}} .
\end{aligned}
$$

$f$ is relative contribution of water generated by methane dehydration, while $m$ is the relative contribution of ambient seawater in the fluid (see Fig. 5). $\delta$ represents isotope composition of oxygen and hydrogen. $\delta_{\text {obs }}$ is the observed isotopic composition. $\delta_{\mathrm{mdw}}$ and $\delta_{\mathrm{fld}}$ are isotopic compositions of water in methane hydrates and fluid (ambient seawater + diagenetically processed water), respectively. $\delta_{\mathrm{sw}}$ is the isotopic composition of ambient seawater. $\delta_{\mathrm{djw}}$ is the isotopic composition of diagenetically processed water. $\alpha$ is the isotope fractionation factor of water for methane dehydration. We adapted 1.003 and 1.022 as $\alpha$ values for $\delta^{18} \mathrm{O}_{\mathrm{H} 2 \mathrm{O}}$ and $\delta \mathrm{D}_{\mathrm{H} 2 \mathrm{O}}$, respectively (Matsumoto and Borowski, 2000; Pashkina, and Esikov, 1990).

Applying (2a) to (1a), Eq. (1a) can be rewritten as

$$
\delta_{\mathrm{obs}}=\delta_{\mathrm{fld}}+f \cdot(\alpha-1) \cdot 10^{3} .
$$

Merging (4) and (3a) and since $\delta_{\mathrm{sw}}=0$ in the current study,

$$
\delta_{\mathrm{djw}}=\left(\delta_{\mathrm{obs}}-f \cdot(\alpha-1) \cdot 10^{3}\right) /(1-m) .
$$

Equation (5) shows a relationship between $\delta_{\text {obs }}$ and $\delta_{\mathrm{djw}}$ and is useful in estimating the range of $\delta_{\mathrm{djw}}$ value and the origin of the fluid, however, unique values of $f$ and $m$ cannot be determined in the current study. Thus we constrained possible range of the $\delta_{\mathrm{djw}}$ from the ranges $f$ and $m$. The ranges of $f$ and $m$ were constrained using concentrations of chlorine because water produced during methane hydrate and diagenesis of sediments contain essentially no chlorine and because chlorine is a conservative component of seawater,

$$
\begin{aligned}
& {\left[\mathrm{Cl}^{-}\right]_{\mathrm{obs}}=f \cdot\left[\mathrm{Cl}^{-}\right]_{\mathrm{mdw}}+(1-f) \cdot\left[\mathrm{Cl}^{-}\right]_{\mathrm{fld}}} \\
& {\left[\mathrm{Cl}^{-}\right]_{\mathrm{mdw}}=0 \text { and }\left[\mathrm{Cl}^{-}\right]_{\mathrm{djw}}=0} \\
& {\left[\mathrm{Cl}^{-}\right]_{\mathrm{fld}}=m(1-f) \cdot\left[\mathrm{Cl}^{-}\right]_{\mathrm{sw}}+(1-m)(1-f) \cdot\left[\mathrm{Cl}^{-}\right]_{\mathrm{djw}} .}
\end{aligned}
$$

Applying (2b) for (1b), Eq. (1b) becomes

$$
\left[\mathrm{Cl}^{-}\right]_{\mathrm{obs}}=m(1-f) \cdot\left[\mathrm{Cl}^{-}\right]_{\mathrm{sw}} \cdot
$$


$\left[\mathrm{Cl}^{-}\right]_{\text {sw }}$ is the concentration of $\mathrm{Cl}^{-}$in ambient seawater, $547 \mathrm{mmol} / \mathrm{kg}$ in bottom seawaters. $\left[\mathrm{Cl}^{-}\right]_{\text {obs }}$ is the observed concentration below about $200 \mathrm{~cm}$ bsf $(350 \mathrm{mmol} / \mathrm{kg})$. The relative contribution of ambient seawater $m(1-f)$ is calculated to be 0.64 , while that of other waters (diagenetic and methane dehydration waters) is calculate to be 0.36 . This constrains possible ranges of $f$ and $m$ to 0 $\leq f \leq 0.36$ and $0.64 \leq m \leq 1$. Applying these ranges of $f$ and $m$ and the observed values of $\delta^{18} \mathrm{O}_{\mathrm{H} 2 \mathrm{O}},+5 \%$, and $\delta \mathrm{D}_{\mathrm{H} 2 \mathrm{O}},-15 \%$, to Eq. (5), possible ranges of $\delta^{18} \mathrm{O}_{\mathrm{djw}}$ and $\delta \mathrm{D}_{\text {djw }}$ were estimated: $+15 \% \circ \leq \delta^{18} \mathrm{O}_{\text {djw }} \leq+22 \%$ and $-103 \%$ o $\leq \delta \mathrm{D}_{\mathrm{djw}} \leq-43 \%$.

Mizota and Kusakabe (1994) reported that the average values for $\delta^{18} \mathrm{O}_{\mathrm{H} 2 \mathrm{O}}$ and $\delta \mathrm{D}_{\mathrm{H} 2 \mathrm{O}}$ of meteoric water in the southern Japan are around $-5 \%$ and $-30 \%$, respectively. These values are quite different from the ranges of $\delta^{18} \mathrm{O}_{\mathrm{H} 2 \mathrm{O}}$ and $\delta \mathrm{D}_{\mathrm{H} 2 \mathrm{O}}$ of diagenetic water estimated in this study as shown in Fig. 4(b) (Craig, 1961; Mizota and Kusakabe, 1994). It clearly supports that meteoric water had negligible contribution to the diagenetically processed fluid in the current study. The estimated ranges of $\delta^{18} \mathrm{O}_{\mathrm{H} 2 \mathrm{O}}$ and $\delta \mathrm{D}_{\mathrm{H} 2 \mathrm{O}}$ of diagenetic water have been reported in various geological settings and explained by the formation of water by mineral dehydration (Magaritz and Gat, 1981; Capuano, 1992; Sheppard and Gilg, 1996; Hensen et al., 2007). Capuano (1992) predicted that water from dehydrating smectite has $\delta^{18} \mathrm{O}_{\mathrm{H} 2 \mathrm{O}}$ values ranging from +7 to $+14 \%$ and $\delta \mathrm{D}_{\mathrm{H} 2 \mathrm{O}}$ from -45 to $-25 \%$. Magaritz and Gat (1981) reported that clay mineral dehydration in oceanic sediments yielded water with $\delta^{18} \mathrm{O}$ ranging from +11.5 to $+28.5 \%$ and $\delta \mathrm{D}$ from -87 to $-55 \%$. These values are comparable to our estimated $\delta^{18} \mathrm{O}_{\mathrm{djw}}$ and $\delta \mathrm{D}_{\mathrm{djw}}$, which supports clay mineral dehydration as the primary source of diagenetic water in the Tanegashima mud volcano.

Fluids from deeper depth migrated through the sediment usually undergo various complicated diagenetic processes under different environmental conditions and geological settings. Thus in many cases it is quite difficult to isolate a specific fluid and identify its origin or processes that it experiences (Dahlman and de Lange, 2003; Hensen et al., 2007). However, current study shows that different sets of geochemical data, such as chemical and isotopic compositions are useful to characterize diagenetic processes.

\section{SUMMARY}

In a mud volcano off Tanegashima Island between Ryukyu trench and Ryukyu arc of Japan, pore waters were collected at four sites. Concentrations of $\mathrm{Cl}^{-}, \mathrm{SO}_{4}{ }^{2-}, \mathrm{CH}_{4}$, and $\mathrm{C}_{2} \mathrm{H}_{6}$ in pore waters, and the stable isotopic composition of $\delta^{13} \mathrm{C}_{\mathrm{CH} 4}, \delta^{18} \mathrm{O}_{\mathrm{H} 2 \mathrm{O}}$, and $\delta \mathrm{D}_{\mathrm{H} 2 \mathrm{O}}$ of pore waters show variations with distances from seafloor. A simple mixing model was applied to explain the observed results below
$280 \mathrm{~cm}$ bsf in the summit site (CV), in which unusual depth profiles of chemical concentrations and isotopic compositions were observed. Because unusually high concentration of $\mathrm{CH}_{4}$ compared to other sites and the conditions at the site is in the stability field of methane hydrate, the existence of methane hydrates is suggested at the $\mathrm{CV}$ site. The depth profiles of $\delta^{18} \mathrm{O}_{\mathrm{H} 2 \mathrm{O}}$ and $\delta \mathrm{D}_{\mathrm{H} 2 \mathrm{O}}$ of the pore water showed an opposite depth dependence, and only $\delta^{18} \mathrm{O}_{\mathrm{H} 2 \mathrm{O}}$ showed a decreasing depth profile similar to that of the concentrations of $\mathrm{Cl}^{-}$. These relationships could not be explained by a simple dilution of the pore water by water dissociated from methane hydrates. Thus a mixing model of three different source waters was considered; ambient seawater, water dissociated from methane hydrates, and diagenetic water ascending from deeper depth. Isotopic fractionation during methane hydrate dissociation was also considered and applied to the model. Using the concentrations of $\mathrm{Cl}^{-}$as a conservative component of seawater, contribution of ambient seawater was estimated to be $64 \%$, whereas $36 \%$ from diagenetic fluid and water dissociated fron iethane hydrates. The estimated relative contributions constrained the possible ranges of isotopic compositions of the diagenetic water to range from +15 to $+22 \%$ for $\delta^{18} \mathrm{O}_{\mathrm{djw}}$ and from -103 to $-43 \%$ for $\delta \mathrm{D}_{\mathrm{djw}}$. The data support that clay mineral dehydration contributes to the diagenetic water.

Acknowledgments - This paper is dedicated to the memory of Dr. Hitoshi Sakai. We are grateful to the captain and crews of R/V Hakurei-maru II, and scientists from MMAJ during Leg 2 and 3 for their skilled work and kind assistance. We thank the two reviewers for their valuable comments and suggestions. NN also thanks Dr. Hiroshi Furutani for stimulative discussions and comments in addition to his kind assistance in preparing manuscript.

\section{REFERENCES}

Bernard, B. B., Brooks, J. M. and Sackett, W. M. (1978) Light hydrocarbons in recent Texas Continental Shelf and Slope sediments. J. Geophys. Res. 83, 4053-4061.

Capuano, R. M. (1992) The temperature dependence of hydrogen isotope fractionation between clay minerals and water: Evidence from a geopressured system. Earth Planet. Sci. Lett. 56, 2547-2554.

Coleman, D. D. and Risatti, J. B. (1981) Fractionation of carbon and hydrogen isotopes by methane-oxidizing bacteria. Geochim. Cosmochim. Acta 45, 1033-1037.

Coleman, M. L., Shepherd, T. J., Durham, J. J., Rouse, J. E. and Moore, G. R. (1982) Reduction of water with zinc for hydrogen isotope analysis. Anal. Chem. 54, 993-995.

Craig, H. (1961) Isotopic variations in meteoric waters. Science 133, 1702-1703.

Dahlmann, A. and de Lange, G. J. (2003) Fluid-sediment interactions at eastern Mediterranean mud volcanoes: a stable isotope study from ODP Leg 160. Earth Planet. Sci. Lett. 212, 377-391. 
Epstein, S. and Mayeda, T. (1953) Variation of ${ }^{18} \mathrm{O}$ content of waters from natural sources. Geochim. Cosmochim. Acta 4, 213-224.

Henry, P., Lepichon, X. and Lallemant, S. (1990) Mud volcano field seaward of the Barbados accretionary complex-a deeptowed side scan sonar survey. J. Geophys. Res. Solid $\mathbf{9 5}$, 8917-8929.

Henry, P., Lepichon, X., Lallemant, S., Lance, S., Martin, J. B., Foucher, J. P., Fiala-Médioni, A., Rostek, F., Guilhaumou, N., Pranal, V. and Castrec, M. (1996) Fluid flow in and around a mud volcano field seaward of the Barbados accretionary wedge: results from Manon cruise. J. Geophys. Res. 101, 20297-20323.

Hensen, C., Nuzzo, M., Hornibrook, E., Pinheiro, L. M., Bock, B., Magalhães, V. and Bruckman, W. (2007) Sources of mud volcano fluids in the Gulf of Cádiz-indications for hydrothermal imprint. Geochim. Cosmochim. Acta 71, 1232-1248.

Hiruta, A., Snyder, G. T., Tomaru, H. and Matsumoto, R. (2009) Geochemical constraints for the formation and dissociation of gas hydrate in an area of high methane flux, eastern margin of the Japan Sea. Earth Planet. Sci. Lett. 279, 326-339.

Hovland, M., Nygaard, E. and Thorbjørnsen, S. (1998) Piercement shale diapirism in the deep-water Vema Dome area, Vøring Basin, offshore Norway. Mar. Petrol. Geol. 15, 191-201.

Kopf, A., Klaeschen, D. and Mascle, J. (2001) Extreme efficiency of mud volcanism in dewatering accretionary prisms. Earth Planet. Sci. Lett. 189, 295-313.

Magaritz, M. and Gat, J. R. (1981) Review of the natural abundance of hydrogen and oxygen isotopes. Stable Isotope Hydrology-Deuterium and Oxygen-18 in the Water Cycle (Gat, J. R. and Gonfiantini, R., eds.), 85-102, Technical Reports Series 210, International Atomic Energy Agency, Vienna.

Manheim, F. T. (1966) A hydraulic squeezer for obtaining interstitial water from consolidated and unconsolidated sediments. U.S. Geol. Surv. Prof. Paper 550-C, 256 pp.

Martin, J. B., Kastner, M., Henry, P. L., Pichon, X. and Lallement, S. (1996) Chemical and isotopic evidence for sources of fluids in a mud volcano field seaward of the Barbados accretionary wedge. J. Geophys. Res. 101, 2032529345.

Marty, D. G. (1993) Methanogenic bacteria in seawater. Limnol. Oceanogr. 38, 452-456.
Matsumoto, R. and Borowski, W. S. (2000) Gas hydrate estimates from newly determined oxygen isotopic fractionation $\left(\alpha_{\mathrm{GH} \_\mathrm{IW}}\right)$ and $\delta^{18} \mathrm{O}$ anomalies of the interstitial waters: Leg 164, Blake Ridge. Proc. ODP Sci. Res. (Paull, C. K., Matsumoto, R., Wallace, P. J. and Dillon, W. P., eds.), 164, 59-66.

Milkov, A. V. (2000) Worldwide distribution of submarine mud volcanoes and associated gas hydrates. Mar. Geol. 167, 2942.

Mizota, C. and Kusakabe, M. (1994) Spatial distribution of $\delta$ D$\delta^{18} \mathrm{O}$ values of surface and shallow groundwaters from Japan, South Korea and East China. Geochem. J. 28, 387410.

Moore, J. C. and Vrolijk, P. (1992) Fluids in accretionary prism. Rev. Geophys. 30, 113-135.

National Oil Corporation (2003) Deep-sea survey for oil resources development-report III. 521 pp. (in Japanese).

Pashkina, V. I. and Esikov, A. D. (1990) Fractionation of oxygen and hydrogen isotopes at the hydrate gas forming in the sea sediments. Isotopenpraxis 26, 600-603.

Paull, C. K., Ussler, W., III and Borowski, W. A. (1994) Sources of biogenic methane to form marine gas-hydrates: In situ production or upwards migration? The New York Academy of Science, Annals 715, 392-409.

Sheppard, S. M. F. and Gilg, H. A. (1996) Stable isotope geochemistry of clay minerals. Clay Miner. 31, 1-24.

Tilbrook, B. D. and Karl, D. M. (1995) Methane sources, distributions and sinks from California coastal waters to the oligotrophic North Pacific gyre. Mar. Chem. 49, 51-64.

Tsunogai, U., Yoshida, N. and Gamo, T. (2002) Carbon isotopic evidence of methane oxidation through sulfate reduction in sediment beneath cold seep vents on the seafloor at Nankai Trough. Mar. Geol. 187, 145-160.

Ujiié, Y. (2000) Mud diapirs observed in two piston cores from the landward slope of the northern Ryukyu Trench, northwestern Pacific Ocean. Mar. Geol. 163, 149-167.

Waseda, A. and Fujii, T. (2007) Origin and migration of gas in gas hydrate-bearing sediments in the Eastern Nankai Trough, Japan. Eos Trans. AGU, 88, Fall Meet. Suppl., Abstract OS12A-04.

Whiticar, M. J. (1999) Carbon and hydrogen isotope systematics of bacterial formation and oxidation of methane. Chem. Geol. 161, 291-314. 